\title{
ISOLATION OF PHOSPHATE-SOLUBILIZING BACTERIA FROM SUBTROPICAL SOILS WITH DIFFERENT FERTILIZATION HISTORIES
}

\author{
ISOLAMENTO DE BACTÉRIAS SOLUBILIZADORAS DE FOSFATO DE SOLOS \\ SUBTROPICAIS COM DIFERENTES HISTÓRICOS DE FERTILIZAÇÃO
}

\begin{abstract}
Juliana Maria MATTER ${ }^{1}$; Silvio César SAMPAIO ${ }^{2}$; Danielle Medina ROSA ${ }^{3}$; Marcelo Bevilacqua REMOR ${ }^{4}$; Kathleen Jeniffer MODEL ${ }^{5}$; Mariana SBIZZARO $^{6}$

1. Bióloga, Doutora pelo Programa de Pós-Graduação em Engenharia Agrícola - PGEAGRI, da Universidade Estadual do Oeste do Paraná. juli_matter@hotmail.com; 2. Engenheiro Agrícola, Docente do Programa de Pós-Graduação em Engenharia Agrícola da Universidade Estadual do Oeste do Paraná; 3. Bióloga, Pós-doutorado, PGEAGRI, Universidade Estadual do Oeste do Paraná; 4. Tecnólogo Ambiental, Pós-doutorando, PGEAGRI, Universidade Estadual do Oeste do Paraná; 5. Bióloga, Doutoranda, PGEAGRI, Universidade Estadual do Oeste do Paraná; 6. Engenheira Ambiental, Doutoranda, PGEAGRI, Universidade Estadual do Oeste do Paraná, Brasil.
\end{abstract}

\begin{abstract}
Phosphorus is one of the most abundant chemical elements but has a low bioavailability index. Therefore, microrganisms play a fundamental role in providing insoluble phosphorus to plants. The objective of this study was to evaluate the capacity of bacteria to solubilize inorganic phosphates in soils with different fertilization histories. Soil and rhizosphere samples were collected from a Red Distroferric Latosol, including a control without mineral or organic fertilizer (C), treatment with mineral fertilizer (MF) according to the needs of each crop, and treatment with organic fertilizer $\left[300 \mathrm{~m}^{3} \mathrm{ha}^{-1}\right.$ of swine wastewater (SW)]. The medium containing calcium phytate presented more colony-forming units (CFU) for all fertilization histories, and growth in treatments $\mathrm{C}$ and MF was 50\% higher than treatment with SW. CFU values in soils treated with SW were lower than those in the other treatments, and the diversity of insoluble phosphate-solubilizing bacteria (PSB) was higher in treatment C. These results indicate a negative relationship between phosphorus concentrations and the number of PSB.
\end{abstract}

KEYWORDS: Calcium phytate. Aluminum phosphate. Calcium phosphate.

\section{INTRODUCTION}

The presence of nutrients in the soil is essential for agricultural productivity. Among the nutrients required by plants, phosphorus constitutes a paradox because it is one of the most abundant chemical elements in the earth's crust but has the lowest bioavailability index, i.e., low solubility and high fixation in soil. The limited bioavailability of phosphorus in the soil limits agricultural productivity requiring replacing this element to meet the needs of the crops. However, in contact with soil, a percentage of the bioavailable phosphorus is immobilized by sorption and precipitation (AWAIS et al., 2017; ZHU; LI.; WHELAN, 2018).

The adequate amount of nutrients in the soil depends on each crop. However, phosphorus deserves special attention because, in contact with the soil, reacts rapidly with the medium and is converted into forms that plants cannot uptake. Phosphorus unavailability is accentuated in soils of tropical regions because the bioavailable phosphorus reacts with $\mathrm{Al}^{3+}$ and $\mathrm{Fe}^{3+}$ in acidic soils and with $\mathrm{Ca}^{2+}$ in alkaline or calcareous soils, and these elements remain immobilized to the soil in the form of aluminum phosphates, iron phosphates, and calcium phosphates (ZHU; LI; WHELAN, 2018). A strategy to increase phosphorus availability in agricultural systems is using microorganisms.

This strategy involves identifying, characterizing, and quantifying the ability of phosphate-solubilizing bacteria (PSB) to solubilize insoluble phosphates, and produce viable cultures to increase the efficiency of inoculation of these bacteria into crops. The strong potential of PSB to solubilize inorganic phosphates and the high environmental sustainability of this process (similar to that of nitrogen fixation in the soil) may help increase phosphate solubility in the soil. Thus, to relate microorganisms with high capacity of solubilization of nutrients in their inorganic form to the plants, it becomes a valuable tool. In this perspective, Lira-Cadete et al. (2012) evidenced the genetic variability of diazotrophic bacteria in the solubilization of inorganic phosphates in the sugarcane crop, which demonstrated satisfactory results both in the solubility capacity and in the genetic variability presented. In this respect, research aimed at obtaining PSB has been conducted in Brazil (ESTRADA-BONILLA et al., 
2017), Amazon region (OLIVEIRA-LONGATTI et al., 2014), semi-arid region of Brazil (LIMA et al., 2014), subtropical soils in China (ZHU et al., 2011), subtropical soils in Pakistan (AWAIS et al., 2017), volcanic soils in Chile (MILKO et al., 2008), grassland soils in Uruguay (AZZIZA et al., 2012), and mangrove soils in India (BEHERA et al., 2014).

Some genera of PSB were found in these regions, including Pseudomonas, Bacillus, Rhizobium, Enterobacter, Achrobacter (NISHA et al., 2014), Arthrobacter, Serratia (CHEN et al., 2006), Pantoea (PARK et al., 2011), Kushneria, Halomonas (ZHU et al., 2011), Azospirillum, Azotobacter (KHAN et al., 2009), Aeromonas, Alcaligenes, Pasteurella (CORDERÓ; SIERRA; JÍMENEZ, 2014), Acinetobacter, and Bradyrhizobium (OLIVEIRA-LONGATTI et al., 2014). It is important to note that phosphates solubilized by bacteria may be inorganic (CHEN et al., 2006; PARK et al., 2011) or organic (phytates) (NISHA et al., 2014).

There is little information on PSB in the western region of the state of Paraná, Brazil, characterized by soils with high agricultural production capacity, livestock production, and extensive environmental and water reserves. The objective of this study was to evaluate the phosphate-solubilizing ability of bacteria in soils with different fertilization histories.

\section{MATERIAL AND METHODS}

Soil and rhizosphere samples were collected from an experimental area established in 2006, cultivated in succession with soybean, corn, and oats, totaling 18 crop cycles by 2014 . According to the treatments applied in each crop cycle (KESSLER et al., 2014), three distinct soil types were selected for sample collection: control without fertilization (C), soil treated with mineral fertilizer (MF) according to the needs of each crop, and soil treated with organic fertilizer $\left[300 \mathrm{~m}^{3} \mathrm{ha}^{-1}\right.$ of swine wastewater (SW)]. Maize (variety $\mathrm{CD} 316$, extraearly hybrid, for off-season production) was used as the bait plant, and the soil of the study area was classified as Red Dystroferric Latosol (CEMBRANEL et al., 2017).

\section{Bacterial cultures}

One gram of root fragments with soil aggregate was transferred to $25 \mathrm{~mL}$ of sterile saline solution (8.5 $\left.\mathrm{g} \mathrm{L}^{-1} \mathrm{NaCl}\right)$ (MILKO et al., 2008) and shaken for $10 \mathrm{~min}$. After that, the samples were diluted successively to $10^{-10}$. Each dilution was performed in triplicate, and $100-\mu \mathrm{L}$ aliquots were transferred to sterile Petri dishes with rich media (PDA Acumedia ${ }^{\circledR}$ ) and to minimum media containing calcium phosphate, aluminum phosphate, and calcium phytate, all in insoluble forms. The plates were kept in an oven for 4 days at $30{ }^{\circ} \mathrm{C}$. The screening media were prepared according to the minimum requirements for microbial development adapted from Milko et al. (2008).

The isolates grown in the minimum medium were transferred to the screening media for two continuous subcultures to confirm colony growth and solubilization ability. This subculturing technique (replica-picking) was performed by transferring cells from the inoculum to a series of replicate plates. Therefore, each replicate plate was inoculated with cells in the same arrangement (LEDERBERG; LEDERBERG, 1951).

The percentage of microbial growth was determined by counting colony-forming units $(\mathrm{CFU})$. The results were related with those obtained from microbial growth in the culture media containing one type of insoluble phosphate in each soil to compare the number of PSB and their solubilization capacity after subculturing.

\section{Soil analysis}

The soil samples were collected after maize crop management in the $0.00-0.20 \mathrm{~m}$ layer for measuring $\mathrm{pH}, \mathrm{MO}, \mathrm{P}, \mathrm{S}, \mathrm{H}^{+} \mathrm{Al}^{3+}$ (exchangeable acidity), $\mathrm{Ca}^{2+}, \mathrm{Mg}^{2+}, \mathrm{K}, \mathrm{Na}^{+}, \mathrm{Mn}, \mathrm{Cu}^{+2}, \mathrm{Fe}, \mathrm{Zn}^{+2}$, total $\mathrm{N}$, inorganic $\mathrm{N}$, organic $\mathrm{N}, \mathrm{NO}_{3}{ }^{-}+\mathrm{NO}_{2}{ }^{-}$, and $\mathrm{NH}_{4}{ }^{+}$, as proposed by EMBRAPA (2009).

\section{Statistical analysis}

The difference between the number of CFU as a function of the type of fertilization and the culture medium used for microbial growth was obtained by analysis of variance and Duncan's mean test at a level of significance of 5\%. The analysis of variance and the mean test were performed using a randomized factorial design $\left(3^{2}\right)$ including the history of soil fertilization (C, MF, and SW), three levels (calcium phosphate, aluminum phosphate, and calcium phytate, all in insoluble form), and three replicates, totaling 27 sampling units.

Data on the number of CFU were subjected to the Shapiro-Wilk normality test and Bartlett's variance homogeneity test, both at a level of significance of 5\%. The tests indicated that the data were normal $(\mathrm{p}=0.282)$ and variance was homogeneous $(\mathrm{p}=0.758)$.

The soil variables that interfered with the number of CFU were identified using Pearson's linear correlation at a level of significance of $5 \%$. 


\section{RESULTS AND DISCUSSION}

The dilution chosen for comparing soil samples was $10^{-2}$ because it presented higher CFU in all soils. There was a statistical difference between the numbers of CFU between the different culture media (Figure 1). The number of CFU was higher in the medium containing insoluble calcium
MATTER et al.

phytate for all fertilization histories and increased by $50 \%$ in treatments $\mathrm{C}$ and MF. In general, the mechanism of phosphate mineralization by bacteria is associated with the release of low molecular weight organic acids (BEHERA et al., 2014) whereas the release of phosphate ions from phytates depends on phytase enzymes.

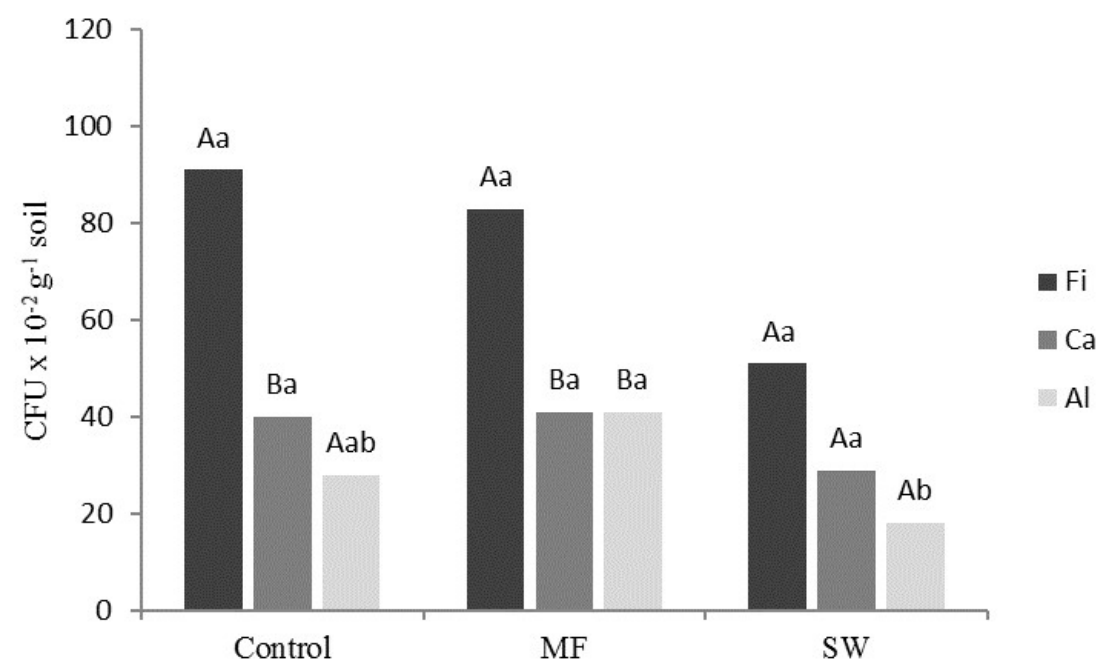

Figure 1. Effect of fertilization history and culture medium on the number of colony-forming units.

The means were compared using Duncan's test at a level of significance of 5\%. Uppercase letters indicate comparisons of fertilization between culture media at each soil layer, and lowercase letters indicate comparisons of fertilization in each culture medium. C, control soil without fertilization; MF, soil treated with mineral fertilizer; SW, soil treated with swine wastewater. $\mathrm{CP}$, calcium phytate; $\mathrm{Ca}_{3}\left(\mathrm{PO}_{4}\right)_{2}$, calcium phosphate; $\mathrm{AlPO}_{4}$, aluminum phosphate.

Phytase production by PSB in this soil was higher than their capacity to solubilize insoluble phosphates, although this production was affected by the fertilization history. The soil treated with SW presented lower CFU, especially for $\mathrm{AlPO}_{4}$, which may be related to the higher availability of phosphorus from fertilization. For this reason, bacteria do not need to use energy to perform solubilization.

The stability of the isolated PSB to solubilize inorganic phosphates was higher when the medium contained calcium phytate and was of the same type, and this capacity varied between $55 \%$ and $70 \%$ (Table 1). The stability varied from $54 \%$ to $66 \%$ for calcium phosphate and from $48 \%$ to $63 \%$ for aluminum phosphate. In contrast, bacteria grown in a growth medium and subcultured in another screening medium had a higher ability to solubilize insoluble calcium phosphate and aluminum phosphate compared to calcium phytate $(60-88 \%$ of bacteria that solubilized calcium phosphate also solubilized calcium phytate, and $59-92 \%$ of bacteria that solubilized aluminum phosphate also solubilized calcium phytate).
Bashan, Kamnev and Bashan (2014) have shown that the primary mechanisms of phosphate solubilization in plants and microorganisms are $\mathrm{H}^{+}$ excretion, production of organic acids, and biosynthesis of acid phosphatase. Therefore, the metabolic pathways involved in the mineralization of organic phosphates appear to be more prevalent in bacteria from the analyzed soil than pathways involved in the solubilization of inorganic phosphates such as calcium phosphate and aluminum phosphate.

The soil treated with MF showed higher stability of solubilization of phosphates after receiving bacteria from the media containing inorganic phosphate. The evaluated soil was treated with phosphate fertilizer and consequently may contain higher concentrations of insoluble phosphates because of the chemical reaction with soil ions. Therefore, the bacteria in this soil can solubilize both inorganic phosphates. Moreover, some bacterial species can mineralize organic phosphates and solubilize inorganic phosphates (BEHERA et al., 2014). 
Table 1. Percentage stability of the capacity to solubilize inorganic phosphates after subculturing of each screening medium.

Stability of the capacity to solubilize inorganic phosphates

\begin{tabular}{|c|c|c|c|c|c|c|}
\hline & Control & & Mineral fe & & $\begin{array}{l}\text { Swine wa } \\
\mathrm{h}^{-1} \text { ) }\end{array}$ & vater $\left(300 \mathrm{~m}^{3}\right.$ \\
\hline \multirow{4}{*}{$\begin{array}{l}\text { Subculture } \\
\text { medium } \\
\% \text { growth }\end{array}$} & $\mathrm{CP}$ & $\%$ & $\mathrm{CP}$ & $\%$ & $\mathrm{CP}$ & $\%$ \\
\hline & $\mathrm{CP}$ & 70 & $\mathrm{CP}$ & 58 & $\mathrm{CP}$ & 55 \\
\hline & $\mathrm{Ca}_{3}\left(\mathrm{PO}_{4}\right)_{2}$ & 42 & $\mathrm{Ca}_{3}\left(\mathrm{PO}_{4}\right)_{2}$ & 49 & $\mathrm{Ca}_{3}\left(\mathrm{PO}_{4}\right)_{2}$ & 36 \\
\hline & $\mathrm{AlPO}_{4}$ & 41 & $\mathrm{AlPO}_{4}$ & 41 & $\mathrm{AlPO}_{4}$ & 29 \\
\hline \multirow{4}{*}{$\begin{array}{l}\text { Subculture } \\
\text { medium } \\
\% \text { growth }\end{array}$} & $\mathrm{Ca}_{3}\left(\mathrm{PO}_{4}\right)_{2}$ & $\%$ & $\mathrm{Ca}_{3}\left(\mathrm{PO}_{4}\right)_{2}$ & $\%$ & $\mathrm{Ca}_{3}\left(\mathrm{PO}_{4}\right)_{2}$ & $\%$ \\
\hline & $\mathrm{CP}$ & 60 & $\mathrm{CP}$ & 88 & $\mathrm{CP}$ & 70 \\
\hline & $\mathrm{Ca}_{3}\left(\mathrm{PO}_{4}\right)_{2}$ & 54 & $\mathrm{Ca}_{3}\left(\mathrm{PO}_{4}\right)_{2}$ & 66 & $\mathrm{Ca}_{3}\left(\mathrm{PO}_{4}\right)_{2}$ & 58 \\
\hline & $\mathrm{AlPO}_{4}$ & 48 & $\mathrm{AlPO}_{4}$ & 72 & $\mathrm{AlPO}_{4}$ & 70 \\
\hline \multirow{4}{*}{$\begin{array}{l}\text { Subculture } \\
\text { medium } \\
\% \text { growth }\end{array}$} & $\mathrm{AlPO}_{4}$ & $\%$ & $\mathrm{AlPO}_{4}$ & $\%$ & $\mathrm{AlPO}_{4}$ & $\%$ \\
\hline & $\mathrm{CP}$ & 92 & $\mathrm{CP}$ & 74 & $\mathrm{CP}$ & 59 \\
\hline & $\mathrm{Ca}_{3}\left(\mathrm{PO}_{4}\right)_{2}$ & 50 & $\mathrm{Ca}_{3}\left(\mathrm{PO}_{4}\right)_{2}$ & 64 & $\mathrm{Ca}_{3}\left(\mathrm{PO}_{4}\right)_{2}$ & 57 \\
\hline & $\mathrm{AlPO}_{4}$ & 56 & $\mathrm{AlPO}_{4}$ & 63 & $\mathrm{AlPO}_{4}$ & 48 \\
\hline
\end{tabular}

$\mathrm{CP}$, calcium phytate; $\mathrm{Ca}_{3}\left(\mathrm{PO}_{4}\right)_{2}$, calcium phosphate; $\mathrm{AlPO}_{4}$, aluminum phosphate.

Pearson's linear correlation analysis indicated that the only soil attribute with a significant positive effect on the total number of CFU was $\mathrm{pH}$ (Table 2), but the correlation coefficient was low (0.39), suggesting that the identified PSB belong to groups that can tolerate and/or adapt to the $\mathrm{pH}$ range of screening media (phytate, 6.13; $\mathrm{Ca}_{3}\left(\mathrm{PO}_{4}\right)^{2}, 6.32$; and $\mathrm{AlPO}_{4}$, 4.4. The soil $\mathrm{pH}$ is determinant for microbial activity and distribution. In addition, higher $\mathrm{pH}$ values promote the increase in bacterial populations because bacteria usually have a low tolerance to more acidic soils, except for some bacterial groups. Moreover, there is evidence that the activity of PSB is higher in soils treated with organic fertilizers such as SW (ZHU; LI; WHELAN, 2018).

Table 2. Pearson correlation between the number of colony-forming units and the physical-chemical characteristics of the soil.

\begin{tabular}{ll}
\hline Soil variables & Total CFU \\
\cline { 2 - 2 } $\mathrm{pH}$ & Pearson \\
$\mathrm{OM}$ & $0.39^{*}$ \\
$\mathrm{P}$ & -0.26 \\
$\mathrm{~S}$ & $-0.51^{*}$ \\
$\mathrm{H}+\mathrm{Al}$ & -0.37 \\
$\mathrm{Ca}$ & -0.31 \\
$\mathrm{Mg}$ & 0.24 \\
$\mathrm{~K}$ & 0.35 \\
$\mathrm{Na}$ & $-0.46^{*}$ \\
$\mathrm{Mn}$ & -0.23 \\
$\mathrm{Cu}$ & -0.24 \\
$\mathrm{Fe}$ & -0.37 \\
$\mathrm{Zn}$ & 0.12 \\
$\mathrm{NH}_{4}$ & $-0.42^{*}$ \\
$\mathrm{NO}_{3}+\mathrm{NO}_{2}$ & -0.10 \\
$\mathrm{Inorganic} \mathrm{N}$ & -0.36 \\
Organic N & -0.35 \\
\hline
\end{tabular}

*Significant at a level of significance of $5 \%$

The negative correlation between phosphate levels and the number of CFU indicates that the higher the availability of phosphorus, the lower is the tendency of bacteria to use metabolic pathways to solubilize this element. Mikanová and Nováková (2002) found that the effect of the exogenous level 
of phosphorus in the bacterial microenvironment affected the solubilization of phosphates by PSB. In the presence of soluble phosphorus, solubilization was repressed in some bacterial species but not affected in other species. However, further studies on the total number of PSB and their solubilization capacity are necessary.

The correlation between the chemical elements and CFU can be a result of chance because these elements were present in higher amounts in soils treated with SW and mineral fertilizer (Table 3). Silva Filho and Vidor (2001) have shown that the capacity and potential of phosphate solubilization by microorganisms vary according to the nutritional factors in the medium. For instance, high levels of $\mathrm{K}$ increase the size of the bacterial colonies. However, some $\mathrm{K}$ levels tend to decrease the solubilization capacity of PSB.

Table 3. Mean concentration of phosphorus, potassium, and zinc in the soil of each treatment.

\begin{tabular}{llll}
\hline \multirow{2}{*}{ Treatments } & \multicolumn{3}{l}{ Mean concentration in the soil } \\
\cline { 2 - 4 } & $\mathrm{P}\left(\mathrm{mg}^{-3} \cdot \mathrm{dm}^{-3}\right)$ & $\mathrm{K}\left(\mathrm{mmol} \cdot \mathrm{dm}^{-3}\right)$ & $\mathrm{Zn}\left(\mathrm{mg} \cdot \mathrm{dm}^{-3}\right)$ \\
\hline Control & 3.33 & 1.10 & 4.50 \\
Mineral fertilizer & 9.67 & 1.63 & 3.10 \\
Swine wastewater & 20.00 & 3.30 & 43.47 \\
\hline
\end{tabular}

$\mathrm{Zn}$ is used in large-scale in pig rations to prevent disease, improve digestion, and promote animal growth. Therefore, a higher amount of this element was expected in SW. The negative correlation between $\mathrm{Zn}$ and the number of CFU may be related to $\mathrm{Zn}$ concentration in the soil because insoluble $\mathrm{Zn}$ is not very attractive to microorganisms, and few strains adapt to environments with high $\mathrm{Zn}$ concentrations (DINESH et al., 2018).

\section{CONCLUSION}

The diversity of PSB is higher in soils with low availability of phosphorus. Given that these microorganisms use mineralization pathways involved in phosphorus metabolism, especially the insoluble organic form. The stability of the capacity to solubilize phosphates needs to be determined to ensure that the selected bacteria can maintain this capacity during several cycles of subculturing, in media with a calcium phytate concentration higher than those others medium used. The higher is the phosphorus concentration in the medium, the lower is the number of PSB, as observed in soils treated with SW.

\section{ACKNOWLEDGMENTS}

To the Higher Institute of Agronomy of the University of Lisbon for research funding, to the Coordination for the Improvement of Higher Education Personnel (CAPES) for providing a doctoral scholarship, and to $\mathrm{CNPq}$ (Processo número: 30484/2013-0) for project funding.

RESUMO: O fósforo é um dos elementos químicos mais abundantes, mas tem um baixo índice de biodisponibilidade. Portanto, micro-organismos desempenham um papel fundamental no fornecimento de fósforo insolúvel para as plantas. O objetivo deste trabalho é avaliar a capacidade das bactérias em solubilizar fosfatos inorgânicos em solos com diferentes históricos de fertilização. Amostras de solo e rizosfera foram coletadas de um Latossolo Vermelho Distroférrico, incluindo controle sem adubação mineral ou orgânica (C), tratamento com adubação mineral (MF) de acordo com as necessidades de cada cultura e tratamento com adubação orgânica $\left[300 \mathrm{~m}^{3} \mathrm{ha}^{-1}\right.$ de águas residuárias da suinocultura (SW)]. O meio contendo fitato de cálcio apresentou mais unidades formadoras de colônias (UFC) para todas as histórias de fertilização, e o crescimento nos tratamentos $\mathrm{C}$ e MF foi $50 \%$ maior que o tratamento com SW. Os valores de CFU nos solos tratados com SW foram menores que nos demais tratamentos, e a diversidade de bactérias insolúveis solubilizadoras de fosfato (PSB) foi maior no tratamento C. Esses resultados indicam uma relação negativa entre as concentrações de fósforo e o número de PSB.

PALAVRAS-CHAVE: Fitato de cálcio. Fosfato de alumínio. Fosfato de cálcio. 


\section{REFERENCES}

AWAIS, M.; TARIQ, M.; ALI, A.; ALI, Q.; KHAN, A.; TABASSUM, B.; NASIR, I. A.; HUSNAIN, T. Isolation, characterization and inter-relationship of phosphate solubilizing bacteria from the rhizosphere of sugarcane and rice. Biocatalysis and Agricultural Biotechnology, v. 11, p. 312-321, 2017. https://doi.org/10.1016/j.bcab.2017.07.018

AZZIZA, G.; BAJSAA, N.; HAGHJOUA, T.; TAULÉA, C.; VALVERDEC, Á. Abundance, diversity and prospecting of culturable phosphate solubilizing bacteria on soils under crop-pasture rotations in a no-tillage regime in Uruguay. Applied Soil Ecology, v. 61, p. 320-326, 2012.

https://doi.org/10.1016/j.apsoil.2011.10.004

BASHAN, Y.; KAMNEV, A. A.; DE-BASHAN, L. E. Tricalcium phosphate is inappropriate as a universal selection factor for isolating and testing phosphate-solubilizing bacteria that enhance plant growth: a proposal for an alternative procedure. Biology and Fertility of soils, v. 49, n. 4, p.465-479, 2014.

https://doi.org/10.1007/s00374-012-0737-7

BEHERA, B.C.; SINGDEVSACHAN, S. K.; MISHRA, R. R.; DUTTA S. K.; THATOI, H. N. Diversity, mechanism and biotechnology of phosphate solubilizing microorganism in mangrove - A Review. Biocatalysis and Agricultural Biotechnology, v. 3, p. 97-110, 2014. https://doi.org/10.1016/j.bcab.2013.09.008

CEMBRANEL, A.; SAMPAIO, S. C.; REMOR, M. B.; GOTARDO J. T.; ROSA, P. M. D. Geochemical background in an oxisol. Engenharia Agricola, v. 37, p. 565-573, 2017. https://doi.org/10.1590/1809-4430eng.agric.v37n3p565-573/2017

CHEN, Y. P.; REKHA, A. B.; ARUN, F. T.; SHEN, W. A.; YOUNG, C. C. Phosphate solubilizing bacteria from subtropical soil and their tricalcium phosphate solubilizing abilities. Taiwan. Applied Soil Ecology, v. 34, p. 33-41, 2006. https://doi.org/10.1016/j.apsoil.2005.12.002

CORDERÓ, A. P.; SIERRA, A. T.; JÍMENEZ, D. A. Actividad in vitro de bactérias endófitas fijadoras de nitrógeno y solubilizadoras de fosfatos. Agronomía mesoamericana, v. 25, p. 213-223, 2014.

https://doi.org/10.15517/am.v25i2.15425

DINESH, R.; SRINIVASANA, V.; HAMZAA, S.; SARATHAMBALA, C.; ANKE GOWDAA, S. J.; GANESHAMURTHYB, A. N.; GUPTAC, S. B.; APARNA NAIRC, V.; SUBILAA, K. P.; LIJINAA, A.; DIVYA, V. C. Isolation and characterization of potential Zn solubilizing bacteria from soil and its effects on soil $\mathrm{Zn}$ release rates, soil available Zn and plant Zn contente. Geoderma, v. 321, p. 173-186, 2018.

https://doi.org/10.1016/j.geoderma.2018.02.013

EMBRAPA. Empresa Brasileira De Pesquisa Agropecuária. Manual de Análises químicas de solo, plantas e fertilizantes. $2^{\circ}$ ed. Brasília, DF: Embrapa informações Tecnológica, 2009. 627 p.

ESTRADA-BONILLA, A. A.; LOPES, C. M.; DURRER, A.; ALVES, P. R. L.; PASSAGLIA, N.;

CARDOSO, E. J. B. N. Effect of phosphate-solubilizing bacteria on phosphorus dynamics and the bacterial community during composting of sugarcane industry waste. Systematic and Applied Microbiology, v. 40, n. 5, p.308-313, 2017. https://doi.org/10.1016/j.syapm.2017.05.003

KESSLER, N. C. H., SAMPAIO, S. C., SORACE, M., LUCAS, S. D., PALMA, D. Swine wastewater associated with mineral fertilization on corn crop (Zea mays). Engenharia Agrícola, v. 34, n. 3, p. 554-566, 2014. https://doi.org/10.1590/S0100-69162014000300018

KHAN, A. A; JILANI, G; AKHTAR, M. S; NAQVI, S. M, S; RASHEED, M. Phosphorus Solubilizing Bacteria: Occurrence, Mechanisms and their Role in Crop Production. Journal of agricultural and biological sciences, v. 1, p. 48-58, 2009. 
LEDERBERG, J.; LEDERBERG, E. M. Replica planting and indirect selection of bacterial mutants. Journal of Bacteriology, v. 63, p. 399-406, 1951. https://doi.org/10.1128/JB.63.3.399-406.1952

LIMA, J. V. L.; PINHEIRO, M. DE S.; FIÚZA, L. M. C. G.; MARTINS, S. C. S.; MARTINS, C. M. Populações microbianas cultiváveis do solo e de serrapilheira de uma unidade de conservação no semiárido brasileiro. Enciclopédia Biosfera, v. 10, n.18, p. 2300 - 2316, 2014.

LIRA-CADETE, L.; FARIAS, A. R. B.; RAMOS, A. P. S.; COSTA, D. P.; FREIRE, F. J.; KUKLINSKYSOBRAL, J. Variabilidade genética de bactérias diazotróficas associadas a plantas de cana-de-açúcar capazes de solubilizar fosfato inorgânico. Bioscience Journal, v. 28, n. 1, p. 122-129. 2012.

MIKANOVÁ, O.; NOVÁKOVÁ, J. Evaluation of the P-solubilizing activity of soil microorganisms and its sensitivity to soluble phosphate. Rostlinná Výroba, v. 48, p. 397 - 400, 2002. https://doi.org/10.17221/4386PSE

MILKO, A. J.; HERNÁNDEZ, M. T.; RENGEL, Z.; MARSCHNER, P.; MOURA, M. DE LA L. Isolation of culturable phosphobacteria with both phytate-mineralization and phosphate-solubilization activity from the rhizosphere of plants grown in a volcanic soil. Biology and Fertility of Soils. v. 44, p. 1025-1034, 2008. https://doi.org/10.1007/s00374-008-0288-0

NISHA, K.; PADMA DEVI, S. N.; VASANDHA, S.; SUNITHA KUMARI, K. Role of phosphorous solubilizing microorganisms to eradicate $\mathrm{P}$ - deficiency in plants: A review. International Journal of Scientific and Research Publications. v. 4, n 7, p. 3, 2014.

OLIVEIRA-LONGATTI, S. M. DE; MARRA, L. M.; SOARES, B. L.; BOMFETI, C. A.; SILVA, K. DA; FERREIRA, P. A. A.; MOREIRA, F. M. DE S. Bacteria isolated from soils of the western Amazon and from rehabilitated bauxite-mining areas have potential as plant growth promoters. World Journal Microbiology Biotechnology, v. 30, p. 1239-1250, 2014. https://doi.org/10.1007/s11274-013-1547-2

PARK, J. H.; BOLAN, N.; MALLAVARAPU, M.; RAVI, N. Isolation of phosphate solubilizing bacteria and their potential for lead immobilization in soil. Journal of Hazardous Materials, v. 185, p. 829-836, 2011. https://doi.org/10.1016/j.jhazmat.2010.09.095

SILVA FILHO, G. N., VIDOR, C. Atividade de microrganismos solubilizadores de fosfatos na presença de nitrogênio, ferro, cálcio e potássio. Pesquisa agropecuária brasileira, v. 36, n. 12, p. 1495-1508, 2001. https://doi.org/10.1590/S0100-204X2001001200007

ZHU, F.; QU, L; HONG, X; SUN, X. Isolation and characterization of a phosphate-solubilizing halophilic bacterium Kushneria sp. YCWA18 from Daqiao Saltern on the coast of Yellow Sea of China. Evidence-Based Complementary and Alternative Medicine, vol. 2011, Article ID 615032, 6 pages, 2011. https://doi.org/10.1155/2011/615032

ZHU, J.; LI, M.; WHELAN, M. Phosphorus activators contribute to legacy phosphorus availability in agricultural soils: A review. Science of the Total Environment, v. 612, p. 522-537, 2018.

https://doi.org/10.1016/j.scitotenv.2017.08.095 